\title{
Ligand-Specific Regulation of the Endogenous Mu-Opioid Receptor by Chronic Treatment with Mu-Opioid Peptide Agonists
}

\author{
Marianna Murányi, ${ }^{1}$ Resat Cinar, ${ }^{1}$ Orsolya Kékesi, ${ }^{1}$ Erika Birkás, ${ }^{1}$ Gabriella Fábián, ${ }^{1}$ \\ Beáta Bozó, ${ }^{1}$ András Zentai, ${ }^{1,2}$ Géza Tóth, ${ }^{1}$ Emese Gabriella Kicsi, ${ }^{1}$ Mónika Mácsai, ${ }^{2}$ \\ Roberta Dochnal, ${ }^{2}$ Gyula Szabó, ${ }^{2}$ and Mária Szüics ${ }^{1}$ \\ ${ }^{1}$ Institute of Biochemistry, Biological Research Center, Hungarian Academy of Sciences, P.O. Box 521, Szeged 6701, Hungary \\ ${ }^{2}$ Department of Pathophysiology, Faculty of Medicine, University of Szeged, Szeged, Hungary
}

Correspondence should be addressed to Mária Szücs; szucsm@hotmail.com

Received 30 April 2013; Revised 22 August 2013; Accepted 6 September 2013

Academic Editor: Eiichi Kumamoto

\begin{abstract}
Copyright (C) 2013 Marianna Murányi et al. This is an open access article distributed under the Creative Commons Attribution License, which permits unrestricted use, distribution, and reproduction in any medium, provided the original work is properly cited.

Since the discovery of the endomorphins (EM), the postulated endogenous peptide agonists of the mu-opioid receptors, several analogues have been synthesized to improve their binding and pharmacological profiles. We have shown previously that a new analogue, cis-1S,2R-aminocyclohexanecarboxylic acid ${ }^{2}$-endomorphin-2 (ACHC-EM2), had elevated mu-receptor affinity, selectivity, and proteolytic stability over the parent compound. In the present work, we have studied its antinociceptive effects and receptor regulatory processes. ACHC-EM2 displayed a somewhat higher (60\%) acute antinociceptive response than the parent peptide, EM2 (45\%), which peaked at $10 \mathrm{~min}$ after intracerebroventricular (icv) administration in the rat tail-flick test. Analgesic tolerance developed to the antinociceptive effect of ACHC-EM2 upon its repeated icv injection that was complete by a 10-day treatment. This was accompanied by attenuated coupling of mu-sites to G-proteins in subcellular fractions of rat brain. Also, the density of mu-receptors was upregulated by about $40 \%$ in the light membrane fraction, with no detectable changes in surface binding. Distinct receptor regulatory processes were noted in subcellular fractions of rat brains made tolerant by the prototypic full mu-agonist peptide, DAMGO, and its chloromethyl ketone derivative, DAMCK. These results are discussed in light of the recently discovered phenomenon, that is, the "so-called biased agonism" or "functional selectivity".
\end{abstract}

\section{Introduction}

Recently discovered endomorphin-1 (Tyr-Pro-Trp-Phe- $\mathrm{NH}_{2}$ EM1) and endomorphin-2 (Tyr-Pro-Phe-Phe- $\mathrm{NH}_{2}$, EM2), which display high affinity and selectivity to mu-opioid receptors, proved to be effective against neuropathic and inflammatory pain with reduced side effects $[1,2]$. Besides their essential pharmacophoric groups $\left(\mathrm{Tyr}^{1}, \mathrm{Phe}^{3}\right.$, and the amidated C-terminus), they have a proline in the second position that serves as a stereochemical spacer. Substitution of Pro $^{2}$ by alicyclic beta-amino acids has been shown to cause profound changes in bioactive conformation, proteolytic stability, and pharmacological activity [3]. Endomorphin-2 containing cis- $(1 R, 2 S)-\mathrm{ACPC}^{2}$ residue (ACHC-EM2) displayed higher binding affinity, improved mu-receptor selectivity, and enhanced proteolytic stability compared to the parent peptide $[3,4]$. These features make it a promising tool to study the conformational requirements of peptide binding to mu-receptor.

Opioids are among the most commonly used analgesics, but their clinical use is limited by the development of various unwanted side effects such as tolerance, physical dependence, and respiratory suppression. It has become apparent that analgesic tolerance and dependence are very complex phenomena, which involve changes at the cellular, neuronal, and system levels [5-9]. Traditionally, receptor desensitization (uncoupling the receptor and G-protein), internalization (trafficking the cell surface receptors into an intracellular 
compartment), and/or downregulation (decrease in the total number of receptors) have been proposed as possible mechanisms for tolerance [6-15]. Importantly, while endogenous opioid peptides efficiently desensitized and internalized muopioid receptors, the highly addictive morphine failed to induce measurable changes [11-18]. There are conflicting data whether there is a linear relationship between the intrinsic efficacy of a ligand and its ability to promote receptor internalization [19-22]. Whistler and colleagues have suggested that receptor endocytosis plays a protective role in reducing the development of tolerance $[8,15,23]$. Another new hypothesis is that opioid tolerance may also result from amplification or induction of an opioid receptor-coupled signal transduction pathway that is either poorly expressed or absent from opioid naive tissue [24]. Very recently, it has been revealed that the mu-opioid receptors, besides other G-protein coupled receptors, display "functional agonism," also called "agonistdirected trafficking" or "biased agonism" implying that different agonists, while acting at the same receptor site, can induce distinct molecular changes and activate distinct downstream responses $[25,26]$.

Most works on opioid receptor trafficking were carried out in various in vitro cell models. The limitations of these models are obvious, including differences in cellular milieu and receptor expression levels. The study of endogenous opioid receptors using in vivo models has produced some interesting results that could not have been anticipated in vitro [27]. As part of a comprehensive work using various mu-opioid ligands of distinct efficacy, chemical nature, and abuse potential, we attempt to correlate receptor regulatory changes with analgesic tolerance. It has been shown that sustained morphine treatment of rats, leading to analgesic tolerance, did not change the density or G-protein coupling of the surface mu-opioid receptors. However, significant intracellular changes, including upregulation of the musites and their cognate G-proteins, were noted in the light membrane fraction [28]. In addition, we have described that 14-methoxymetopon, an extremely potent, centrally acting mu-opioid specific analgesic with low tolerance, physical dependence, and other side effects, when given to rats either acutely or chronically, did not change the binding or Gprotein signaling of mu-opioid receptors in rat brain subcellular membranes [29]. We have hypothesized that whereas surface opioid receptors and their cognate G-proteins mediate the acute effect of opioids, intracellular events may play a crucial role in the long-term changes elicited by chronic drug exposure [28].

In the present work, we have examined the new endomorphin analogue, ACHC-EM2, for its antinociceptive effect and receptor regulatory changes after acute and prolonged in vivo treatments. The model system used is based on subcellular fractionation of rat brains followed by ligand binding and functional measurements. Detailed characterization of the subcellular fractions by marker enzymes, electron microscopy, and receptor binding experiments has been reported [28-31]. To assess changes in the intracellular distribution of mu-opioid receptors, subcellular fractionation was combined with radioligand binding measurements. The degree of desensitization was estimated by ligand-stimulated guanosine- $5^{\prime}-\mathrm{O}-(3-[\gamma$ $\left[{ }^{35} \mathrm{~S}\right]$ hio)triphosphate, $\left[{ }^{35} \mathrm{~S}\right] \mathrm{GTP} \gamma \mathrm{S}$ functional assays. It is concluded that the regulatory changes accompanying $\mathrm{ACHC}$ EM2 analgesic tolerance are distinct from those of the prototypic mu-agonist peptide, DAMGO (Tyr-D-Ala-Gly(NMe)Phe-Gly-ol), and its chloromethyl derivative, DAMCK (Tyr-D-Ala-Gly-(NMe)Phe- $\mathrm{CH}_{2} \mathrm{Cl}$ ).

\section{Materials and Methods}

2.1. Chemicals. Endomorphin derivatives were synthesized as published [3]. DAMGO and $\left[{ }^{3} \mathrm{H}\right] \mathrm{DAMGO}(36 \mathrm{Ci} / \mathrm{mmol})$ were prepared and kindly provided to us by Drs. Farkas and Tóth (Biological Research Center, Szeged, Hungary) or purchased from Multiple Peptide System (San Diego, CA, USA). DAMCK was synthesized as published [32] by Anna Magyar (ELTE, Budapest, Hungary). $\left[{ }^{35} \mathrm{~S}\right] \mathrm{GTP} \gamma \mathrm{S}$ was obtained from Isotope Institute Ltd. (Budapest, Hungary). Tris(hydroxymethyl)aminomethane, (Tris, free base), sodium chloride $(\mathrm{NaCl})$, ethylenebis(oxyethylenenitrilo) tetraacetic acid (EGTA), guanosine $5^{\prime}$-diphosphate sodium salt (GDP), guanosine $5^{\prime}$-triphosphate sodium salt (GTP), guanosine $5^{\prime}$ - $[\gamma$-thio]triphosphate tetralithium salt (GTP- $\gamma$ $\left.\mathrm{S}-\mathrm{Li}_{4}\right)$, magnesium chloride hexahydrate $\left(\mathrm{MgCl}_{2} \times 6 \mathrm{H}_{2} \mathrm{O}\right)$, dithiothreitol, sucrose, and Nembutal were purchased from Sigma-Aldrich (St. Louis, MO, USA). Bradford reagent was from Bio-Rad Laboratories (Hercules, CA, USA).

2.2. Animals. Wistar rats (250-500 g) were used. They were kept under a standard light-dark cycle with food and water available ad libitum. The animals were kept and treated according to the rules of the Ethical Committee for the Protection of Animals in Research (University of Szeged and Biological Research Center of the Hungarian Academy of Sciences, Szeged, Hungary). All efforts were made to minimize their suffering during treatments. The animals were randomly assigned to treatment groups ( $n=4 /$ dose/treatment).

2.3. Surgery. For intracerebroventricular (icv) peptide administration, the rats were implanted with a stainless steel Luer cannula (10 $\mathrm{mm}$ long) aimed at the right lateral cerebral ventricle under Nembutal $(35 \mathrm{mg} / \mathrm{kg}$, intraperitoneally) anesthesia [32]. The stereotaxic coordinates were $0.2 \mathrm{~mm}$ posterior, $1.7 \mathrm{~mm}$ lateral to the bregma, and $3.7 \mathrm{~mm}$ deep from the dural surface, according to the atlas of Pellegrino et al. [33]. Cannulas were secured to the skull with dental cement and acrylate. The experiments were started 5 days after $i c v$ cannulation. All icv treatments were delivered to freely moving animals to prevent unspecific effects. Upon conclusion of the experiments, $10 \mu \mathrm{L}$ of methylene blue was injected into the ventricle of decapitated animals and the position of the cannula was inspected visually. Animals with improper cannula placement were excluded from the final statistical analysis.

2.4. In Vivo Opioid Treatments. The peptides were dissolved in artificial cerebrospinal fluid (CSF) and injected in a volume of $2 \mu \mathrm{L}$. Endomorphins were administered either acutely at 
the indicated doses $(100 \mathrm{pg}-20 \mu \mathrm{g})$ or chronically at $20 \mu \mathrm{g}$ for 10 days (twice daily) and tested at the indicated times. Vehicle control groups obtaining CSF were used in all experiments, and no changes were detected in the antinociceptive response of the control group. DAMGO and DAMCK were injected at $10 \mu \mathrm{g}$ twice daily for 8 days. Animals were killed $16 \mathrm{hrs}$ after drug treatments by decapitation immediately followed by subcellular fractionation.

2.5. Tail-Flick (TF) Antinociceptive Assay. The original method of D'Amour was used to determine analgesia in the rat by measuring the time required to respond to a radiating heat stimulus [32]. A beam light was focused on the tip of the tail, and the latency required for the rat to remove its tail was determined before (baseline) and after drug administration. The animals were tested at the times shown after injection of the peptides. The antinociceptive effect was expressed according to the equation: $\left(\mathrm{TF}_{n}-\mathrm{TF}_{o}\right) \times 100 / \mathrm{TF}_{\max }-\mathrm{TF}_{o}$, where $\mathrm{TF}_{o}$ is the tail-flick latency before drug administration, $\mathrm{TF}_{n}$ is the value of a repeated corresponding measurement after drug injection, and $\mathrm{TF}_{\max }$ indicates the cutoff time which was set at $10 \mathrm{sec}$ in our assays. Statistical analysis of the data of tail-flick antinociceptive test was made by ANOVA. For significant ANOVA values, groups were compared by Tukey's test for multiple comparisons with unequal cell size. A probability level, $P<0.05$, was accepted to label significant differences.

2.6. Crude Rat Brain Membranes. Crude brain membranes were prepared as published [34]. Briefly, pooled brain tissues without cerebella of four rats were washed with ice-cold buffer and their weight was measured. They were homogenized in 30 volumes (v/w) of ice-cold $50 \mathrm{mM}$ Tris- $\mathrm{HCl}$ buffer $(\mathrm{pH} 7.4)$. Homogenates were centrifuged at $20,000 \times \mathrm{g}$ for $25 \mathrm{~min}$, and the resulting pellets suspended in buffer and spun again. Pellets were taken up in the original volume of buffer and incubated for $30 \mathrm{~min}$ at $37^{\circ} \mathrm{C}$, followed by centrifugation at $20,000 \times \mathrm{g}$ for $25 \mathrm{~min}$. The supernatants were carefully discarded, and the final pellets were taken up in 5 volumes (v/w) of $50 \mathrm{mM}$ Tris- $\mathrm{HCl}$ buffer ( $\mathrm{pH} 7.4$ ) containing $0.32 \mathrm{M}$ sucrose. Appropriate membrane aliquots were stored at $-80^{\circ} \mathrm{C}$ for several weeks. Prior to the binding experiments, an appropriate aliquot was thawed, diluted with 5-fold Tris-HCl buffer, and centrifuged at 20,000 $\times \mathrm{g}$ for $25 \mathrm{~min}$ to remove sucrose. The resulting pellets were taken up in $50 \mathrm{mM}$ Tris- $\mathrm{HCl}$ buffer ( $\mathrm{pH} 7.4$ ) to yield in $0.3-0.5 \mathrm{mg}$ membrane protein $/ \mathrm{mL}$.

2.7. Subcellular Fractionation of Rat Brains. Subcellular fractions of rat brains were purified as published [28, 29]. Briefly, fresh forebrains of four rats were pooled, gently homogenized in 10 volumes $(\mathrm{v} / \mathrm{w})$ of ice-cold buffer $(5 \mathrm{mM}$ Tris- $\mathrm{HCl} \mathrm{pH}$ 7.4, $50 \mu \mathrm{M} \mathrm{CaCl}_{2}, 0.5 \mathrm{mM}$ dithiothreitol), and supplemented with $10 \%$ sucrose. All sucrose solutions were made in the above buffer. The homogenate was spun at $1,000 \times \mathrm{g}$ for $10 \mathrm{~min}$. The resulting pellet was resuspended in the above buffer and spun again. The combined supernatants were spun at $12,000 \times \mathrm{g}$ for $20 \mathrm{~min}$. The pellets were suspended in
$10 \%$ sucrose and subjected to consecutive centrifugations at $20,000 \times \mathrm{g}$ for $25 \mathrm{~min}$ and $14,000 \times \mathrm{g}$ for $20 \mathrm{~min}$ twice resulting in crude synaptic plasma membranes (SPM). The resulting pellets were lysed followed by fractionation on a $10 \%, 28.5 \%$, and $34 \%$ sucrose density step gradient that was spun at $100,000 \times \mathrm{g}$ for $2 \mathrm{~h}$. Highly enriched SPMs were obtained from the $28 / 34 \%$ interface. Crude microsomal (MI) fractions were obtained from the $12,000 \times \mathrm{g}$ supernatant by consecutive centrifugations at $20,000 \times \mathrm{g}$ for $25 \mathrm{~min}$ and $100,000 \times \mathrm{g}$ for $1 \mathrm{~h}$. MI fractions were purified on a $10 \%$ and $28.5 \%$ sucrose step gradient centrifuged at $100,000 \times \mathrm{g}$ for $2 \mathrm{~h}$ and collected at 10/28.5\% interface. SPM and MI fractions were diluted threefold with $50 \mathrm{mM}$ Tris- $\mathrm{HCl}$ buffer and pelleted at $100,000 \times \mathrm{g}$ for $1 \mathrm{~h}$ to remove sucrose. The resulting pellets were taken up in $50 \mathrm{mM}$ Tris- $\mathrm{HCl}$ ( $\mathrm{pH} 7.4)$ buffer to yield in 0.3-0.8 mg membrane protein/ml and were freshly used.

2.8. Protein Concentration. The protein content of the membrane preparations was determined by the method of Bradford using bovine serum albumin as a standard [35].

2.9. $\left[{ }^{3} H\right] D A M G O$ Binding Assay. Briefly, homologous displacement assays were performed by incubating $\left[{ }^{3} \mathrm{H}\right] \mathrm{DAMGO}(\approx 1 \mathrm{nM})$ with 11 concentrations of unlabeled DAMGO $\left(10^{-10}-10^{-5} \mathrm{M}\right)$ and the membrane suspension (200-300 $\mu$ g protein) in $50 \mathrm{mM}$ Tris- $\mathrm{HCl}$ ( $\mathrm{pH} 7.4$ ) buffer in a final volume of $1 \mathrm{~mL}$ as described [28, 29]. The tubes were incubated at $25^{\circ} \mathrm{C}$ for $1 \mathrm{~h}$. The reaction was stopped by vacuum filtration through Whatman $\mathrm{GF} / \mathrm{C}$ glass fiber filters (Whatman, Maidstone, England) using a Brandel M24-R Cell Harvester (Brandel, Gaithersburg, MD, USA). Filters were rapidly washed with $3 \times 5 \mathrm{~mL}$ ice-cold $50 \mathrm{mM}$ Tris- $\mathrm{HCl}$ ( $\mathrm{pH}$ 7.4) buffer, air-dried, and counted in a toluene-based scintillation cocktail in a Wallac 1409 scintillation counter (Wallac, Turku, Finland). All experiments were performed in duplicate and repeated at least three times. Curves were constructed and analyzed by means of the GraphPad Prism 4 program (GraphPad Software, Inc., San Diego, CA, USA.) to obtain $K_{D}$ (dissociation constant) and $B_{\max }$ (receptor density) values. The data reported are means \pm S.E.M.

2.10. Ligand-Stimulated $\left[{ }^{35} S\right] G T P \gamma S$ Functional Assay. The assay was performed as published [28, 29] with slight modifications. Briefly, rat brain membrane fractions $(\approx 10 \mu \mathrm{g}$ of protein) were incubated with $\left[{ }^{35} \mathrm{~S}\right] \mathrm{GTP} \gamma \mathrm{S}(0.05 \mathrm{nM})$ and 56 concentrations $\left(10^{-9}-10^{-4} \mathrm{M}\right)$ of opioid peptides in the presence of $100 \mu \mathrm{M}$ GDP in Tris-EGTA (50 mM Tris- $\mathrm{HCl}$, $1 \mathrm{mM}$ EGTA and $5 \mathrm{mM} \mathrm{MgCl}$; pH 7.4) buffer in a total volume of $1 \mathrm{~mL}$ for $60 \mathrm{~min}$ at $30^{\circ} \mathrm{C}$. Nonspecific binding was determined with $10 \mu \mathrm{M}$ GTP $\gamma \mathrm{S}$ and subtracted. Bound and free $\left[{ }^{35} \mathrm{~S}\right] \mathrm{GTP} \gamma \mathrm{S}$ were separated by vacuum filtration through Whatman GF/F filters using a Brandel M24-R Cell Harvester (Brandel, Gaithersburg, MD, USA). Filters were rapidly washed with $3 \times 5 \mathrm{~mL}$ ice-cold $50 \mathrm{mM}$ Tris- $\mathrm{HCl}(\mathrm{pH} 7.4)$ buffer, air-dried, and counted in a toluene-based scintillation cocktail in a Wallac 1409 scintillation counter (Wallac, Turku, Finland). All assays were performed in triplicate and repeated 


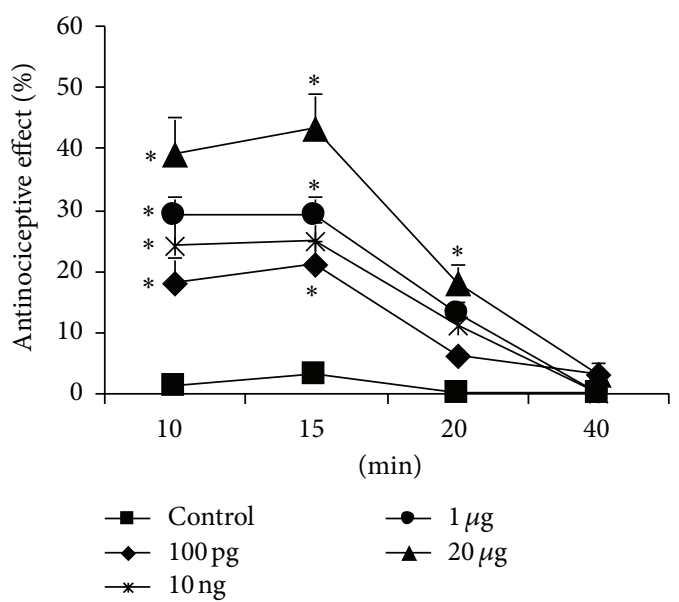

(a)

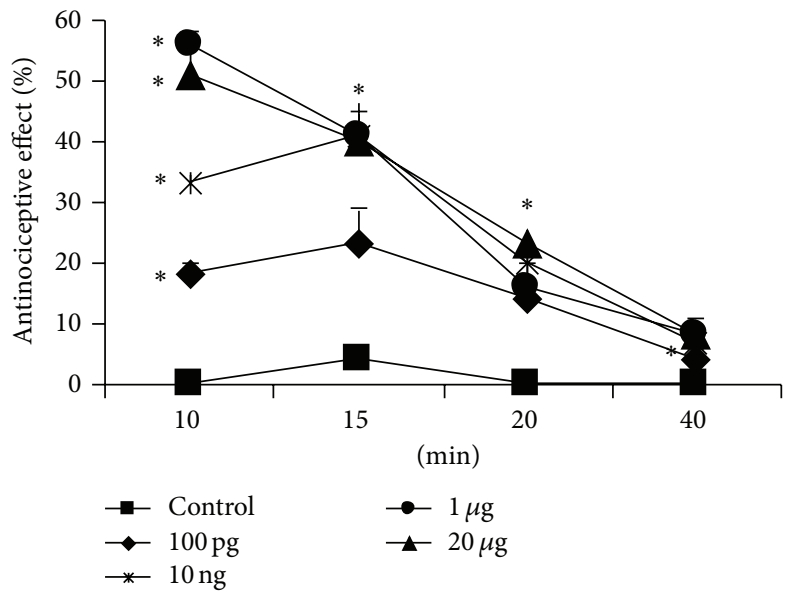

(b)

FIgURE 1: Time-course of the acute antinociceptive effect of graded doses of EM2 (a) and ACHC-EM2 (b) in rat tail-flick assay. The peptides were administered $i c v$ and assayed as described in Methods. Control groups received CSF. Data are shown as mean \pm S.E.M; $n \geq 6$. Statistical significance was determined by ANOVA and set at ${ }^{*} P<0.05$ compared to appropriate control values.

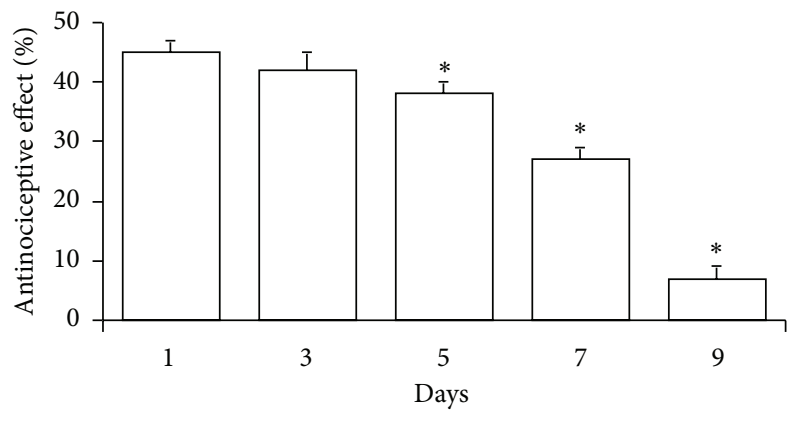

(a)

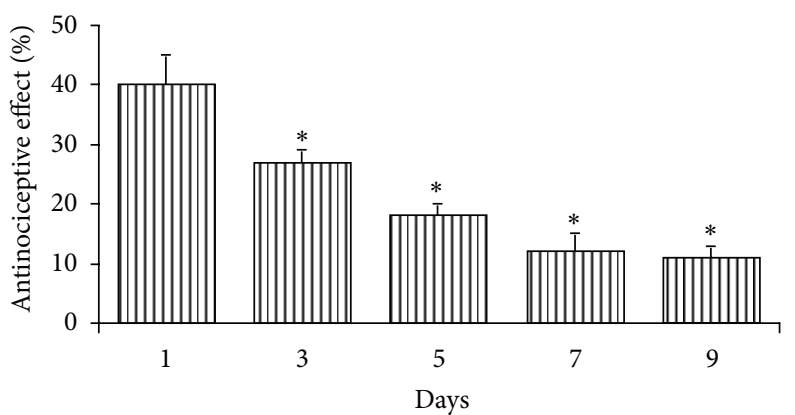

(b)

FIGURE 2: Development of antinociceptive tolerance to chronic ACHC-EM2 given at $20 \mu \mathrm{g} / 2 \mu \mathrm{L}$ twice daily for the indicated time periods. Rats were tested in the tail-flick assay $5 \mathrm{~min}$ (a, white columns) and $15 \mathrm{~min}$ (b, striped columns) after injection. Mean \pm S.E.M.; $n=7$. Significance was determined by ANOVA; * labels $P<0.05$ compared to the first day.

at least three times. Curves were constructed and analyzed by fitting sigmoidal dose-response curves using the GraphPad Prism 4 program (GraphPad Prism Software Inc) to obtain potency $\left(\mathrm{EC}_{50}\right.$, concentration of the ligand to give halfmaximal effect) and efficacy ( $E_{\max }, \%$ maximal stimulation over basal activity) values. Basal activities were measured in the absence of opioid ligands and set as $0 \%$. The data reported are means \pm S.E.M.

\section{Results}

3.1. Antinociceptive Effect of ACHC-EM2 after Acute Treatments. In the first part of the study, the antinociceptive effect of the new ligand, ACHC-EM2, was evaluated and compared to that of its parent peptide, EM2, in tail-flick tests. Rats were injected $i c v$ with different doses of the peptides between $100 \mathrm{pg}$ and $20 \mu \mathrm{g}$ as indicated in Figure 1. Animals treated with lower doses of ACHC-EM2 displayed a concentrationdependent increase $(20-50 \%)$ in analgesic response compared to base-line values. The acute antinociceptive effect peaked around $10-15 \mathrm{~min}$, followed by a rapid decrease, which dissipated by $40 \mathrm{~min}$ following injection (Figure 1). Higher doses ( 1 and $20 \mu \mathrm{g}$ ) of ACHC-EM2 displayed around $60 \%$ antinociceptive responses which were somewhat higher than those of the parent peptide, EM2 (45\%), which peaked at an earlier time (10 $\mathrm{min})$.

3.2. Analgesic Tolerance Develops to the Antinociceptive Effect of ACHC-EM2 after Chronic Treatments. In the next set of experiments, rats were repeatedly injected twice daily with ACHC-EM2 $(20 \mu \mathrm{g}, i c v)$ and the antinociceptive effect was measured 5 and $15 \mathrm{~min}$ following injection on various treatment days. It can be seen that the antinociceptive effect gradually decreased with time compared to day 1, which became statistically significant by day 5 and ceased by day 10 showing the development of analgesic tolerance (Figure 2).

3.3. Potency and Efficacy of ACHC-EM2 in Activating GProteins In Vitro. ACHC-EM2 was measured in the ligandstimulated $\left[{ }^{35} \mathrm{~S}\right] \mathrm{GTP} \gamma \mathrm{S}$ functional assay in crude rat brain 
TABLE 1: Changes in DAMGO-stimulated $\left[{ }^{35} \mathrm{~S}\right] \mathrm{GTP} \gamma \mathrm{S}$ binding induced by in vivo chronic opioid peptide treatments in rat brain subcellular fractions.

\begin{tabular}{|c|c|c|c|c|c|c|c|c|}
\hline \multirow{3}{*}{ Treatment } & \multicolumn{4}{|c|}{$E_{\max }(\%$ over basal $)$} & \multicolumn{4}{|c|}{$\mathrm{EC}_{50}(\mathrm{nM})$} \\
\hline & \multicolumn{2}{|c|}{ SPM } & \multicolumn{2}{|c|}{ MI } & \multicolumn{2}{|c|}{ SPM } & \multicolumn{2}{|c|}{ MI } \\
\hline & Control & Treated & Control & Treated & Control & Treated & Control & Treated \\
\hline ACHC-EM2 & $95 \pm 5$ & $106 \pm 5$ & $85 \pm 9$ & $109 \pm 2$ & $44 \pm 6$ & $80 \pm 8^{*}$ & $100 \pm 18$ & $179 \pm 25^{*}$ \\
\hline DAMGO & $112 \pm 12$ & $130 \pm 14$ & $60 \pm 3$ & $72 \pm 9$ & $87 \pm 9$ & $107 \pm 14$ & $101 \pm 14$ & $86 \pm 2$ \\
\hline DAMCK & $112 \pm 12$ & $100 \pm 9$ & $60 \pm 3$ & $61 \pm 17$ & $87 \pm 9$ & $126 \pm 22$ & $101 \pm 14$ & $200 \pm 42^{*}$ \\
\hline
\end{tabular}

ACHC-EM2, DAMGO, and DAMCK were chronically administered to rats as described in Methods. Control animals received CSF. Subcellular fractionation of brain homogenates to obtain synaptic plasma membrane (SPM) and microsomal (MI) fractions was performed. Full concentration curves of DAMGO, consisting of 5-6 concentrations between $10^{-8}-10^{-4} \mathrm{M}$, were measured in $\left[{ }^{35} \mathrm{~S}\right] \mathrm{GTP} \gamma \mathrm{S}$ binding assay. The parameters shown were obtained from nonlinear regression analysis using Graph Pad Prism 4 considering a sigmoidal dose response curve for DAMGO. Results shown are as \% stimulation of $\left[{ }^{35} \mathrm{~S}\right] \mathrm{GTP} \gamma \mathrm{S}$ binding over basal values (i.e., binding in the absence of DAMGO). Data are mean \pm S.E.M. of 3-6 independent experiments each performed in triplicate. Significant difference between the appropriate values in control and treated membrane fractions was determined by the Student's $t$-test and set as ${ }^{*} P<0.05$.

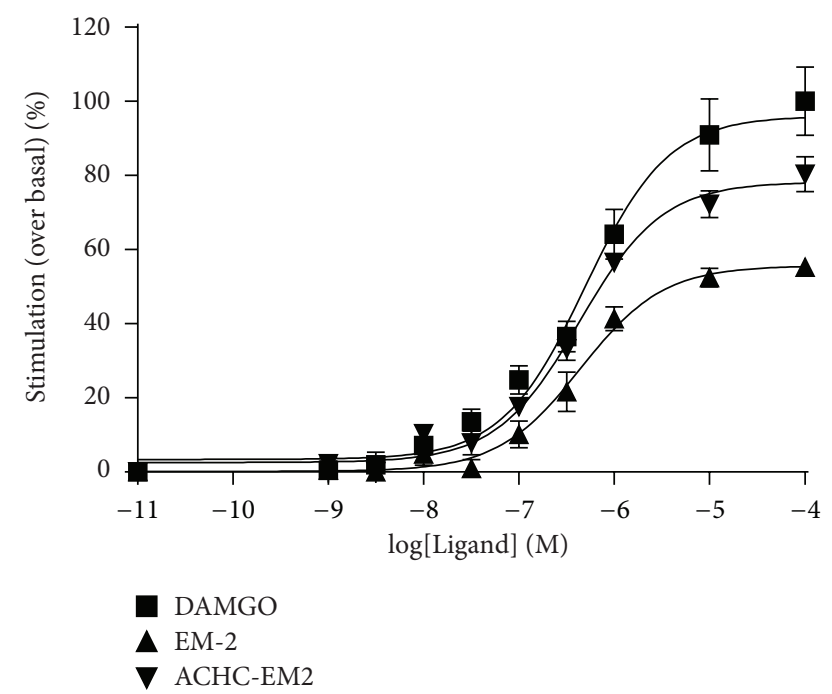

FIGURE 3: Stimulation of $\left[{ }^{35} \mathrm{~S}\right] \mathrm{GTP} \gamma \mathrm{S}$ binding by opioid peptides in crude rat brain membranes. Membrane homogenates $(\approx 10 \mu \mathrm{g}$ of protein) were incubated with increasing concentrations $\left(10^{-9}-\right.$ $\left.10^{-4} \mathrm{M}\right)$ of the indicated ligands and $\left[{ }^{35} \mathrm{~S}\right] \mathrm{GTP} \gamma \mathrm{S}(0.05 \mathrm{nM})$ as described in Methods except that $30 \mu \mathrm{M}$ GDP was used. The curves were fit and drawn by Graph Pad Prism 4 computer program. Results are shown as \% stimulation of $\left[{ }^{35} \mathrm{~S}\right] \mathrm{GTP} \gamma \mathrm{S}$ binding over basal values (i.e., binding in the absence of opioid peptides). Each value represents the mean \pm S.E.M. of at least three independent experiments performed in triplicate. Nonvisible S.E.M. is within the symbol.

membranes and compared to that of EM2 and the prototypic full agonist, DAMGO. Full dose-response curves of the three peptides were assessed between $10^{-9}-10^{-4} \mathrm{M}$ and efficacy and potency values were determined (Figure 3 ). The $E_{\max }$ value of DAMGO was set as $100 \%$ by definition. The efficacy was significantly lower for both ACHC-EM2 and EM2 with $E_{\max }$ values of $71.7 \pm 1.1$ and $52.5 \pm 0.8 \%$, respectively. These data show that both ACHC-EM2 and EM2 behave as partial agonists in this assay. The potency of the three peptides in stimulating G-protein activation was very similar, with $\log \mathrm{EC}_{50}$ value of ACHC-EM2 being $6.37 \pm 0.03$.
3.4. Changes in G-protein Stimulation due to Chronic Treatments with Mu-Opioid Peptide Agonists. Brains exposed to repeated agonists treatments leading to analgesic tolerance or vehicle were simultaneously processed in every experiment. Control and treated brain homogenates were subjected to subcellular fractionation to obtain highly purified SPM and MI membrane fractions. Functional coupling of mu-opioid receptors to G-proteins was examined by measuring the ability of DAMGO, added to the membrane fractions in vitro, to facilitate $\left[{ }^{35} \mathrm{~S}\right] \mathrm{GTP} \gamma \mathrm{S}$ binding (Table 1). The potencies of DAMGO were $44 \pm 6 \mathrm{nM}$ and $100 \pm 18 \mathrm{nM}$, and efficacies of $95 \pm 5$ and $85 \pm 9 \%$ in control (vehicle administered) SPM and MI, respectively. Chronic treatment with ACHCEM2 resulted in a significant shift of the dose-response curve of DAMGO to the right; accordingly the $\mathrm{EC}_{50}$ values of DAMGO increased to $80 \pm 8 \mathrm{nM}$ and $179 \pm 25 \mathrm{nM}$ in treated SPM and MI, respectively. Chronic treatment with DAMCK also resulted in attenuated G-protein coupling in the MI fraction. There was a similar tendency in the SPM which, however, did not reach a statistically significant level. Chronic DAMGO treatment did not cause any change in $\left[{ }^{35} \mathrm{~S}\right] \mathrm{GTP} \gamma \mathrm{S}$ incorporation. The efficacies, reflected in the $E_{\max }$ values, did not change due to any treatments (Table 1 ).

3.5. Changes of Receptor Densities due to Chronic Treatments with Mu-Opioid Peptide Agonists. Changes in the binding parameters of mu-opioid receptors were measured in $\left[{ }^{3} \mathrm{H}\right]$ DAMGO homologous displacement experiments (Table 2). As expected, the $K_{D}$ values were not significantly changed due to acute or chronic ACHC-EM2 treatments. Acute injection of a single dose $(20 \mu \mathrm{g})$ of the endomorphin derivative did not change the $B_{\max }$ values in any fractions. Notably, chronic treatment with this peptide resulted in a significant $(42 \%)$ increase in the density of mu-sites in the MI fraction (Table 2, Figure 4(a)). On the contrary, chronic treatments with the full agonist DAMGO resulted in a $22 \%$ decrease in the density of surface mu-sites (Figure 4(b)). Similar effect was detected with the chloromethyl ketone derivative of DAMGO, DAMCK, with a concomitant $40 \%$ increase in the MI fractions (Figure 4(c)). 


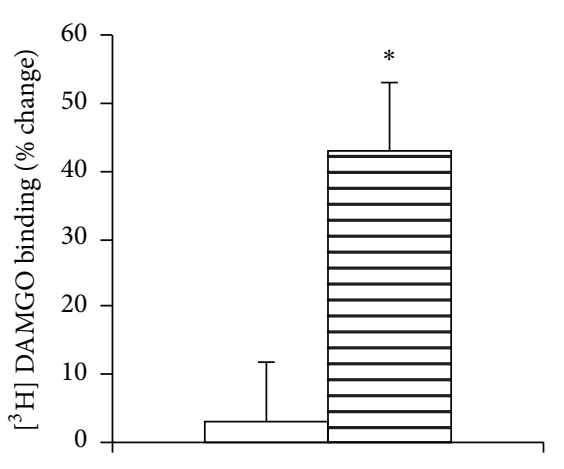

(a)

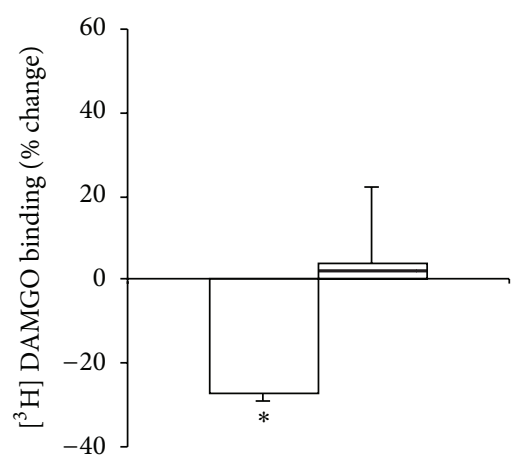

(b)

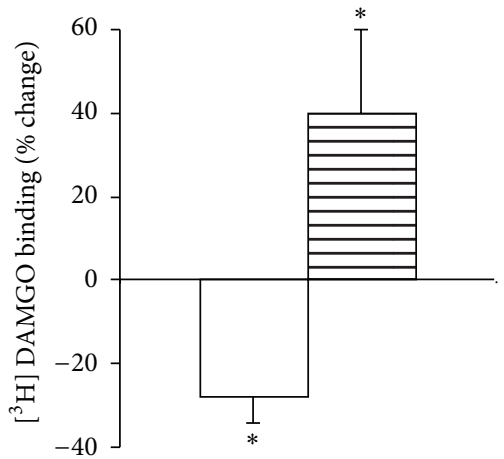

(c)

Figure 4: Changes in receptor density $\left(B_{\max }\right)$ following chronic exposure of ACHC-EM2 (a) DAMGO (b), and DAMCK (c). SPM (white columns) and MI (striped columns) fractions were prepared from whole brain. The membrane suspensions (0.3 mg protein) were incubated with $1 \mathrm{nM}\left[{ }^{3} \mathrm{H}\right] \mathrm{DAMGO}$ for $60 \mathrm{~min}$ at $25^{\circ} \mathrm{C}$ in the absence (total binding) or in the presence of $10^{-10}-10^{-5} \mathrm{M}$ of unlabeled DAMGO. Results are expressed as $\%$ change of protein in each fraction. Mean \pm S.E.M.; $n=3-6$; significance was determined by $t$-test; ${ }^{*} P<0.05$ compared to control.

TABLE 2: Changes in $\left[{ }^{3} \mathrm{H}\right]$ DAMGO binding induced by ACHC-EM2 treatments in rat brain subcellular fractions.

\begin{tabular}{lcccccccc}
\hline \multirow{2}{*}{$\begin{array}{l}\text { Treatment } \\
\end{array}$} & \multicolumn{2}{c}{ SPM } & \multicolumn{2}{c}{$K_{D}(\mathrm{nM})$} & \multicolumn{3}{c}{$B_{\max }(\mathrm{fmol} / \mathrm{mg}$ protein) } \\
& Control & Treated & Control & Treated & Control & Treated & Control & Treated \\
\hline ACHC-EM2 acute & $5.0 \pm 1.9$ & $3.0 \pm 1.1$ & $2.3 \pm 0.4$ & $3.6 \pm 0.9$ & $298 \pm 72$ & $258 \pm 45$ & $410 \pm 59$ & $311 \pm 74$ \\
ACHC-EM2 chronic & $2.9 \pm 1.2$ & $1.3 \pm 0.2$ & $4.5 \pm 2.4$ & $2.5 \pm 0.2$ & $291 \pm 82$ & $286 \pm 50$ & $333 \pm 78$ & $462 \pm 54^{*}$ \\
\hline
\end{tabular}

ACHC-EM2 was injected either acutely or chronically as described in Methods. Control animals received CSF. Subcellular fractionations of brain homogenates to obtain synaptic plasma membrane (SPM) and microsomal (MI) membranes followed by $\left[{ }^{3} \mathrm{H}\right]$ DAMGO binding was performed as outlined in Methods. Data represent the mean \pm S.E.M. of at least three independent experiments performed in duplicate. Statistically significant differences due to either treatments compared to appropriate control values in each fraction were determined by Student $t$-test and set at ${ }^{*} P<0.05$.

\section{Discussion}

In one part of the work, we have described the pharmacological features of the new endomorphin derivative, ACHCEM2, upon its icv administration in the rat tail-flick test. Acutely, it is slightly more potent than the parent peptide, EM2, having 60 and 45\% maximal antinociceptive effect values, respectively (Figure 1). These results are consistent with several investigations in acute pain tests showing that endomorphins exhibited steady plateau at $40 \%$ of maximal antinociceptive effect [2,36-38]. We have shown previously that the prototypic mu-agonist peptide, DAMGO, and its chloromethyl ketone derivative, DAMCK, display profound antinociception of about $80 \%$ with distinct time-course. The effect of DAMGO was longer-lasting, which peaked by about $30 \mathrm{~min}$ and followed by a rapid dissipation, whereas DAMCK showed an apparently irreversible antinociception [32]. This is in accordance with its irreversible binding to mu-sites in in vitro binding assays. It is to be noted that we have intracerebroventricularly administrated EM2 and ACHC-EM2, while the antinociceptive effects were examined by using the tail-flick test, mostly a spinal reflex. Opioids are involved in both ascending and descending components of pain modulation. Given supraspinally, multiple descending pain control pathways are involved in antinociception induced by opioid agonists. Interestingly, distinct mechanisms mediating descending pain controls for antinociception induced by supraspinally administered EM1 and EM2 were described in the mouse [39].

It has been revealed that full analgesic tolerance develops to the antinociceptive effect of $20 \mu \mathrm{g}$ ACHC-EM2 by a 10 day treatment (icv, twice daily) (Figure 2). For a comparison, tolerance development was also tested for DAMGO and DAMCK. It was found that behavioral tolerance was complete by an 8-day icv injection of $10 \mu \mathrm{g}$ of the latter two peptides (twice daily (data not shown)). For further biochemical studies, the doses of the peptides were designed to maximize tolerance and were not equieffective as performed with other ligands [19].

Since the ligand-stimulated $\left[{ }^{35} \mathrm{~S}\right] \mathrm{GTP} \gamma \mathrm{S}$ functional assay measures receptor mediated G-protein activation, it may be a viable tool to detect adaptations associated with tolerance at the mu-opioid receptor. We have revealed that both EM2 and its new derivative are partial agonists, contrary to the full agonist DAMGO, in the ligand-stimulated $\left[{ }^{35} \mathrm{~S}\right] \mathrm{GTP} \gamma \mathrm{S}$ functional test in crude rat brain membranes (Figure 3). This is in an excellent agreement with our data in the tail-flick analgesia test and recent work, which showed that EM2 has a much lower operational efficacy for G-protein mediated responses than DAMGO at native mu-opioid receptors in mature neurons [40]. However, tolerance to $\left[{ }^{35} \mathrm{~S}\right] \mathrm{GTP} \gamma \mathrm{S}$ incorporation following chronic opioid peptide treatments was not detected in all cases, even when full analgesic 
tolerance was manifested. It was found that chronic ACHCEM2 treatment decreased the $\mathrm{EC}_{50}$ of DAMGO by about 2-fold showing attenuated coupling of mu-sites to their cognate G-proteins in both SPM and MI membranes. Similar changes were observed upon prolonged DAMCK treatment. On the contrary, chronic DAMGO injection resulted in no significant changes in either the potency or in the efficacy of G-protein signaling (Table 1). The question arises whether a different picture would have been obtained on ACHC-EM2stimulated $\left[{ }^{35} \mathrm{~S}\right] \mathrm{GTP} \gamma \mathrm{S}$ signaling. Differences in the pattern of G-protein activation have been reported for agonists at mu-opioid receptors, including EM-1 versus EM2 and EM2 versus DAMGO and morphine [41-43]. In the present work, we did not attempt to identify the G-protein subtypes involved in the effect of each ligand. For detecting desensitization, G-protein activation by the full agonist DAMGO may be a better choice than the partial agonist ACHC-EM2, which may induce either incomplete stimulation of the entire mu-opioid receptor population or full stimulation of only a portion of the entire receptor population. Another reason for testing DAMGO-stimulated $\left[{ }^{35} \mathrm{~S}\right] \mathrm{GTP} \gamma \mathrm{S}$ binding is that the present study is part of a comprehensive work using various mu-opioid ligands of distinct efficacy, chemical nature, and abuse potential to assess regulatory changes due to analgesic tolerance, and this set-up was used in our previous studies $[28,29]$.

Ligand-specific changes were also detected for receptor trafficking (Figure 4). While chronic DAMGO and DAMCK decreased the density of surface mu-receptors, such changes were not evident by ACHC-EM2. Instead, the density of musites increased by about $40 \%$ in the light membrane fraction of ACHC-EM2 tolerant brain homogenates compared to that of vehicle-treated MI fraction (Figure 4(c), Table 2). Previous works from other laboratories have revealed region-specific receptor adaptation in the brain $[42,43]$. It is to be considered whether compounds injected via the icv route are able to reach the entire population of mu-opioid receptors in the central nervous system. There are reports suggesting that the compounds may remain in the vicinity of the ventricles. On the contrary, icv administration of the opioid antagonist beta-funaltrexamine was shown to reduce the density of muopioid receptors as measured by in situ autoradiography by $40-50 \%$ throughout the brain, with little regional variations [44]. Since it is not possible to gain sufficient amount of membrane proteins in subcellular fractions of small tissues, we have measured mu-opioid receptor density in crude membranes. $\left[{ }^{3} \mathrm{H}\right]$ DAMGO binding was downregulated by about $22 \%$ in the hippocampus, upregulated by $33 \%$ in the spinal cord, and did not significantly change in the cortex and brainstem due to chronic ACHC-EM2 treatments (data not shown).

Overall, distinct regulatory changes were noted for the three opioid peptides, albeit all caused full analgesic tolerance. This is in accordance with a growing number of data showing that different opioid ligands can lead to varying degrees of receptor regulation. The recently discovered phenomenon of "biased agonism" can provide the molecular basis for the observed ligand-specific effects. It is anticipated that different agonists stabilize distinct active conformations of the receptor, thereby inducing distinct downstream signaling $[25,26,45]$. A very recent paper has shown that endomorphins seem to be biased toward arrestin recruitment over Gprotein activation contrary to DAMGO [40]. Morphine has been shown to be biased toward $\beta$-arrestin 2 regulation of the mu-opioid receptors. It was published that knocking-out this protein enhanced and prolonged morphine antinociception in the hot-plate test and attenuated tolerance [46]. Although the precise role of arrestins in the regulation of mu-opioid receptors in neurons remains to be fully elucidated, it may explain the observed ligand-specific effects in the present work and others. Functional selectivity may open up new directions for designing potent analgesics with less unwanted side effects.

\section{Conclusions}

Chronic icv treatment with the partial agonist endomorphin analog, ACHC-EM2, resulted in the development of analgesic tolerance in the rat tail-flick test. This was accompanied by desensitization of the mu-receptors in subcellular fractions of rat brain. Also, the mu-receptors were upregulated by about $40 \%$ in the light membrane fraction with no detectable change in surface binding. The prototypic full mu-agonist peptide, DAMGO, and its chloromethyl ketone derivative, DAMCK, also induced tolerance, yet the accompanying molecular changes were different. These results are in accordance with the recently discovered phenomenon, that is, the so-called "biased agonism" or "functional selectivity". The new concept may help to identify new lead molecules, which can substitute morphine in pain treatment with improved pharmacological profile.

\section{Conflict of Interests}

The authors declare no conflict of interests.

\section{Acknowledgments}

This work was supported by NKTH DNT 08/2004, OTKA T 046434, ETT 355-08, and TÁMOP 4.2.2-A-11/1/KONV2012-0052 Research Grants. The technical assistance of Ildikó Németh, Ágnes Paál, and Gusztáv Kis is greatly acknowledged.

\section{References}

[1] J. E. Zadina, L. Hackler, L. J. Ge, and A. J. Kastin, "A potent and selective endogenous agonist for the $\mu$-opiate receptor," Nature, vol. 386, no. 6624, pp. 499-502, 1997.

[2] G. Horvath, M. Szikszay, C. Tömböly, and G. Benedek, "Antinociceptive effects of intrathecal endomorphin-1 and -2 in rats," Life Sciences, vol. 65, no. 24, pp. 2635-2641, 1999.

[3] A. Keresztes, M. Szűcs, A. Borics et al., "New endomorphin analogues containing alicyclic beta-amino acids: influence on bioactive conformation and pharmacological profile," Journal of Medicinal Chemistry, vol. 51, pp. 4270-4279, 2008. 
[4] C. Tömböly, A. Péter, and G. Tóth, "In vitro quantitative study of the degradation of endomorphins," Peptides, vol. 23, pp. 15731580, 2002.

[5] E. J. Nestler, B. T. Hope, and K. L. Widnell, "Drug addiction: a model for the molecular basis of neural plasticity," Neuron, vol. 11, no. 6, pp. 995-1006, 1993.

[6] T. Koch and V. Höllt, "Role of receptor internalization in opioid tolerance and dependence," Pharmacology and Therapeutics, vol. 117, no. 2, pp. 199-206, 2008.

[7] J. T. Williams, S. L. Ingram, G. Henderson et al., "Regulation of $\mu$-opioid receptors: desensitization, phosphorylation, internalization, and tolerance," Pharmacological Reviews, vol. 65, no. 1, pp. 223-254, 2013.

[8] J. L. Whistler, "Examining the role of mu opioid receptor endocytosis in the beneficial and side-effects of prolonged opioid use: from a symposium on new concepts in mu-opioid pharmacology," Drug and Alcohol Dependence, vol. 121, no. 3, pp. 189-204, 2012.

[9] K. Nagi and G. Piñeyro, "Regulation of opioid receptor signalling: implications for the development of analgesic tolerance," Molecular Brain, vol. 4, article 25, 2011.

[10] J. R. Arden, V. Segredo, Z. Wang, J. Lameh, and W. Sadee, "Phosphorylation and agonist-specific intracellular trafficking of an epitope-tagged $\mu$-opioid receptor expressed in HEK 293 cells," Journal of Neurochemistry, vol. 65, no. 4, pp. 1636-1645, 1995.

[11] N. T. Burford, L. M. Tolbert, and W. Sadee, "Specific G protein activation and $\mu$-opioid receptor internalization caused by morphine, DAMGO and endomorphin I," European Journal of Pharmacology, vol. 342, no. 1, pp. 123-126, 1998.

[12] K. Stafford, A. B. Gomes, J. Shen, and B. C. Yoburn, " $\mu$-opioid receptor downregulation contributes to opioid tolerance in vivo," Pharmacology Biochemistry and Behavior, vol. 69, no. 12, pp. 233-237, 2001.

[13] Y. Qiu, P. Y. Law, and H. H. Loh, “ $\mu$-opioid receptor desensitization: role of receptor phosphorylation, internalization, and resensitization," Journal of Biological Chemistry, vol. 278, no. 38, pp. 36733-36739, 2003.

[14] C. Sternini, M. Spann, B. Anton et al., "Agonist-selective endocytosis of $\mu$ opioid receptor by neurons in vivo," Proceedings of the National Academy of Sciences of the United States of America, vol. 93, no. 17, pp. 9241-9246, 1996.

[15] L. Martini and J. L. Whistler, "The role of mu opioid receptor desensitization and endocytosis in morphine tolerance and dependence," Current Opinion in Neurobiology, vol. 17, no. 5, pp. 556-564, 2007.

[16] A. Alt, A. Mansour, H. Akil, F. Medzihradsky, J. R. Traynor, and J. H. Woods, "Stimulation of guanosine-5'-O-(3[35s]thio)triphosphate binding by endogenous opioids acting at a cloned mu receptor," Journal of Pharmacology and Experimental Therapeutics, vol. 286, no. 1, pp. 282-288, 1998.

[17] J. L. Whistler and M. von Zastrow, "Morphine-activated opioid receptors elude desensitization by $\beta$-arrestin," Proceedings of the National Academy of Sciences of the United States of America, vol. 95, no. 17, pp. 9914-9919, 1998.

[18] K. McConalogue, E. F. Grady, J. Minnis et al., "Activation and internalization of the $\mu$-opioid receptor by the newly discovered endogenous agonists, endomorphin-1 and endomorphin-2," Neuroscience, vol. 90, no. 3, pp. 1051-1059, 1999.

[19] A. Duttaroy and B. C. Yoburn, "The effect of intrinsic efficacy on opioid tolerance," Anesthesiology, vol. 82, no. 5, pp. 1226-1236, 1995.
[20] J. McPherson, G. Rivero, M. Baptist et al., “ $\mu$-opioid receptors: correlation of agonist efficacy for signalling with ability to activate internalization," Molecular Pharmacology, vol. 78, no. 4, pp. 756-766, 2010.

[21] M. Pawar, P. Kumar, S. Sunkaraneni, S. Sirohi, E. A. Walker, and B. C. Yoburn, "Opioid agonist efficacy predicts the magnitude of tolerance and the regulation of $\mu$-opioid receptors and dynamin-2," European Journal of Pharmacology, vol. 563, no. 13, pp. 92-101, 2007.

[22] H. Xu, J. S. Partilla, X. Wang et al., "A comparison of noninternalizing (Herkinorin) and internalizing (DAMGO) $\mu$-opioid agonists on cellular markers related to opioid tolerance and dependence," Synapse, vol. 61, no. 3, pp. 166-175, 2007.

[23] A. K. Finn and J. L. Whistler, "Endocytosis of the mu opioid receptor reduces tolerance and a cellular hallmark of opiate withdrawal," Neuron, vol. 32, no. 5, pp. 829-839, 2001.

[24] A. R. Gintzler and S. Chakrabarti, "Opioid tolerance and the emergence of new opioid receptor-coupled signaling," Molecular Neurobiology, vol. 21, no. 1-2, pp. 21-33, 2000.

[25] T. Kenakin, "Functional selectivity through protean and biased agonism: who steers the ship?" Molecular Pharmacology, vol. 72, no. 6, pp. 1393-1401, 2007.

[26] J. D. Urban, W. P. Clarke, M. von Zastrow et al., "Functional selectivity and classical concepts of quantitative pharmacology," Journal of Pharmacology and Experimental Therapeutics, vol. 320, no. 1, pp. 1-13, 2007.

[27] Y. Wang, E. J. van Bockstaele, and L. Y. Liu-Chen, "In vivo trafficking of endogenous opioid receptors," Life Sciences, vol. 83, no. 21-22, pp. 693-699, 2008.

[28] G. Fábián, B. Bozó, M. Szikszay, G. Horváth, C. J. Coscia, and M. Szücs, "Chronic morphine-induced changes in mu-opioid receptors and $G$ proteins of different subcellular loci in rat brain," Journal of Pharmacology and Experimental Therapeutics, vol. 302, pp. 774-780, 2002.

[29] R. Cinar, O. Kékesi, E. Birkás, G. Fábián, H. Schmidhammer, and M. Szücs, "Lack of regulatory changes of mu-opioid receptors by 14-methoxymetopon treatment in rat brain. Further evidence for functional selectivity," Current Pharmaceutical Design. In press.

[30] B. L. Roth, M. B. Laskowski, and C. J. Coscia, "Evidence for distinct subcellular sites of opiate receptors: demonstration of opiate receptors in smooth microsomal fractions isolated from rat brain," Journal of Biological Chemistry, vol. 256, no. 19, pp. 10117-10123, 1981.

[31] M. Szűcs and C. J. Coscia, "Differential coupling of opioid binding sites to guanosine triphosphate binding regulatory proteins in subcellular fractions of rat brain," Journal of Neuroscience Research, vol. 31, no. 3, pp. 565-572, 1992.

[32] G. Szabó, M. Mácsai, E. G. Kicsi et al., "Long-lasting antinociceptive effect of DAMGO chloromethyl ketone in rats," Peptides, vol. 20, no. 11, pp. 1321-1326, 1999.

[33] L. J. Pellegrino, A. S. Pellegrino, and A. J. Cushman, Stereotactic Atlas of the Rat Brain, vol. 8, Plenum, New York, NY, USA, 2nd edition, 1979.

[34] R. Cinar, T. F. Freund, I. Katona, K. Mackie, and M. Szűcs, "Reciprocal inhibition of G-protein signaling is induced by $\mathrm{CB} 1$ cannabinoid and $\mathrm{GABAB}$ receptor interactions in rat hippocampal membranes," Neurochemistry International, vol. 52, no. 8, pp. 1402-1409, 2008.

[35] M. M. Bradford, "A rapid and sensitive method for the quantitation of microgram quantities of protein utilizing the principle 
of protein dye binding," Analytical Biochemistry, vol. 72, no. 1-2, pp. 248-254, 1976.

[36] B. Przewłocka, J. Mika, D. Łabuz, G. Toth, and R. Przewłocki, "Spinal analgesic action of endomorphins in acute, inflammatory and neuropathic pain in rats," European Journal of Pharmacology, vol. 367, no. 2-3, pp. 189-196, 1999.

[37] P. Sánchez-Blázquez, M. Rodríguez-Díaz, I. DeAntonio, and J. Garzón, "Endomorphin-1 and endomorphin-2 show differences in their activation of mu opioid receptor-regulated $G$ proteins in supraspinal antinociception in mice," Journal of Pharmacology and Experimental Therapeutics, vol. 291, pp. 12$18,1999$.

[38] H. Xie, J. H. Woods, J. R. Traynor, and M. C. Ko, “The spinal antinociceptive effects of endomorphins in rats: behavioral and G protein functional studies," Anesthesia and Analgesia, vol. 106, no. 6, pp. 1873-1881, 2008.

[39] M. Ohsawa, H. Mizoguchi, M. Narita, M. Chu, H. Nagase, and L. F. Tseng, "Differential mechanisms mediating descending pain controls for antinociception induced by supraspinally administered endomorphin-1 and endomorphin-2 in the mouse," Journal of Pharmacology and Experimental Therapeutics, vol. 294, no. 3, pp. 1106-1111, 2000.

[40] G. Rivero, J. Llorente, J. McPherson et al., "Endomorphin-2: a biased agonist at the $\mu$-opioid receptor," Molecular Pharmacology, vol. 82, no. 2, pp. 178-188, 2012.

[41] C. S. Breivogel, D. E. Selley, and S. R. Childers, "Acute and chronic effects of opioids on $\delta$ and $\mu$ receptor activation of $\mathrm{G}$ proteins in NG108-15 and SK-N-SH cell membranes," Journal of Neurochemistry, vol. 68, no. 4, pp. 1462-1472, 1997.

[42] P. Sánchez-Blázquez, P. Gómez-Serranillos, and J. Garzón, "Agonists determine the pattern of G-protein activation in mu-opioid receptor-mediated supraspinal analgesia," Brain Research Bulletin, vol. 54, no. 2, pp. 229-235, 2001.

[43] J. Garzón, M. Castro, and P. Sánchez-Blázquez, "Influence of Gz and Gi2 transducer proteins in the affinity of opioid agonists to mu receptors," European Journal of Neuroscience, vol. 10, no. 8, pp. 2557-2564, 1998.

[44] T. J. Martin, S. I. Dworkin, and J. E. Smith, "Effects of intracerebroventricular administration of $\beta$-funaltrexamine on $\left[{ }^{3} \mathrm{H}\right]$ DAMGO binding to rat brain sections," Journal of Pharmacology and Experimental Therapeutics, vol. 267, no. 1, pp. 506514, 1993.

[45] E. Reiter, S. Ahn, A. K. Shukla, and R. J. Lefkowitz, "Molecular mechanism of $\beta$-arrestin-biased agonism at seventransmembrane receptors," Annual Review of Pharmacology and Toxicology, vol. 52, pp. 179-197, 2012.

[46] L. M. Bohn, R. J. Lefkowitz, R. R. Gainetdinov, K. Peppel, M. G. Caron, and F. T. Lin, "Enhanced morphine analgesia in mice lacking $\beta$-arrestin 2," Science, vol. 286, no. 5449, pp. 2495-2498, 1999. 

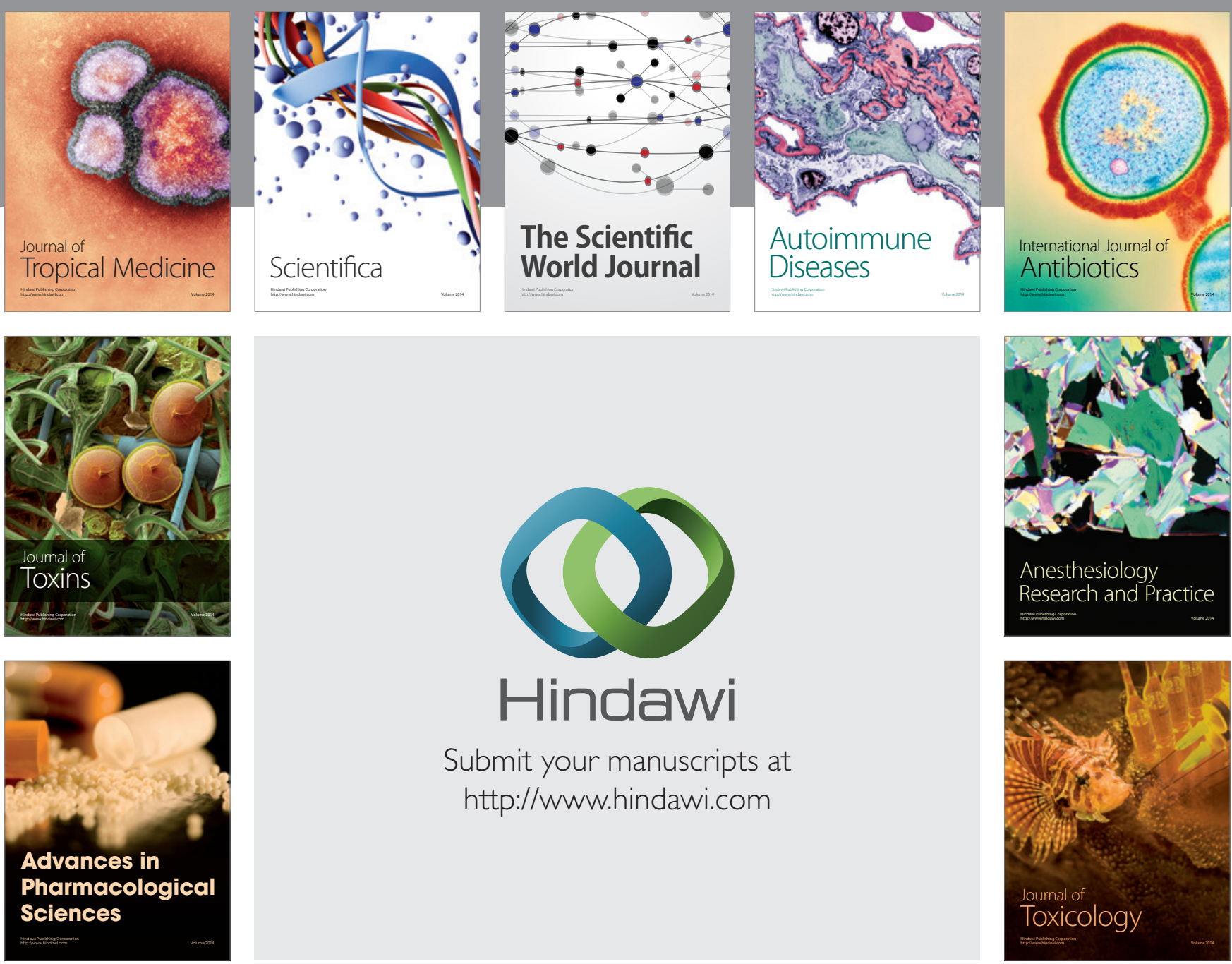

\section{Hindawi}

Submit your manuscripts at

http://www.hindawi.com
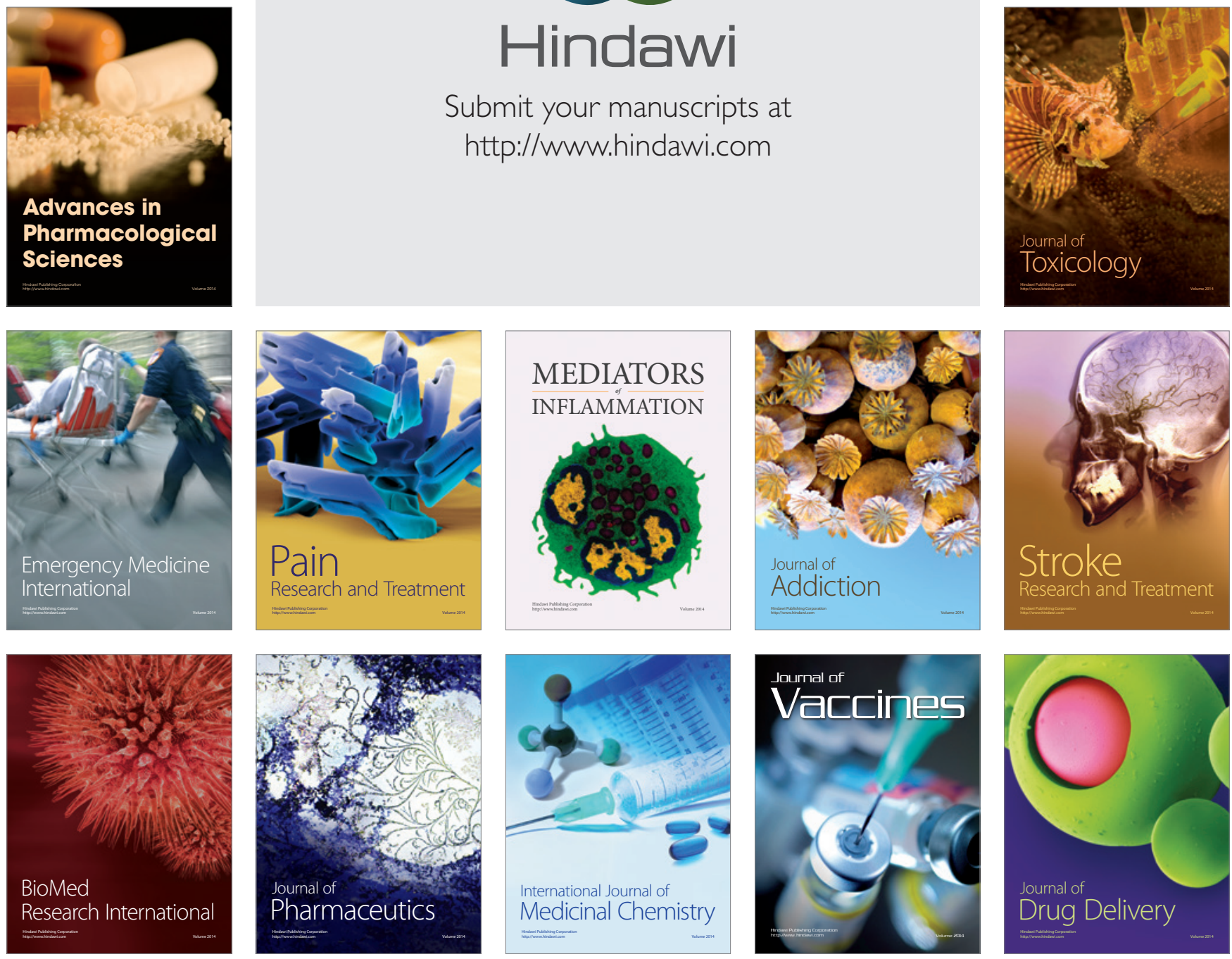